\title{
A COMPREHENSIVE MATHEMATICAL MODEL FOR SIMULATION OF LATENT AND SENSIBLE HEAT LOSSES FROM WET-SKIN SURFACE AND FUR LAYER OF A COW
}

\author{
ZaHid A. KHAN ${ }^{1}$, Irfan ANJUM BadRUddin ${ }^{2 *}$, MOHZANi MoKhtaR ${ }^{2}$, AND W. M. \\ WAN MUHAMAD ${ }^{3}$ \\ 'Department of Mechanical Engineering, Faculty of Engineering and Technology, Jamia Millia \\ Islamia, New Delhi-110 025, INDIA \\ ${ }^{2}$ School of Mechanical Engineering, University Sains Malaysia, 14300 Nibong Tebal, Penang, \\ MALAYSIA. \\ ${ }^{3}$ Faculty of Mechanical Engineering, University Kuala Lumpur, Kuala Lumpur MALAYSIA.
}

Abstract This paper presents a comprehensive mathematical model that calculates heat and mass transfer from the skin surface and fur layer of a cow. The model predicts evaporative, respiratory, convective, radiant and urine heat losses for different levels of skin and fur wetness, air velocity, ambient temperature, relative humidity, breathing rate and volume of urine discharged per unit time. Effect of various environmental conditions on skin temperature and consequently heat loss from cow's body is discussed. It is found that the heat loss through respiration is significant and can not be ignored. Evaporative cooling and respiratory heat losses are, decreased due to increased relative humidity because of increased saturation of ambient air with water particles. It is also found that very small proportion of total body heat is lost through urine in stressful hot environment.

Keywords: Cow; simulation model; sensible heat losses; latent heat losses; wet fur

\section{INTRODUCTION}

It has been reported that thermal environment can adversely affect milk production of dairy cows [1]. Hot and humid environments cause severe heat stress to cows, that results reduction in milk production. In order to increase milk yield of the cows it is necessary to cool them off. An effective cooling method is to wet their hair coat and skin surface by sprinkling water on them [2]. Many other studies (see [3-5]) have also reported that in hot and dry environments, animals can effectively be cooled by applying water onto their hair coat and skin surface. But using water alone to cool them is not as effective as spraying

* Corresponding author: Tel: 604-5937788 ext: 6369, Fax: 604-5941025

E-mail: Irfan_magami@Rediffmail.com 
water and blowing air simultaneously [6]. The body temperature of cows reduces substantially due to the combined effect of wetting and blowing air (see [7-11]). It is observed that when animal is wet then moisture and heat flow takes place much more quickly through a hair coat that has been wetted to the skin [11]. The reported mathematical models (see [12-13]) have demonstrated that the heat loss from the body of cows can be increased significantly and consequently heat stress can effectively be reduced through evaporative cooling by wetting the skin and fur layer followed by blowing air over it. The heat conducted through the skin is taken up by the surface moisture as it evaporates from the wet skin surface and fur layer. This process cools the skin and consequently allows it to take more body heat. The speed with which water vapour moves through the hair coat depends on the velocity of the blowing air. The water vapour moves very slowly under still-air conditions but moves faster with increasing air velocity, and allows moisture to continue evaporating from the wet skin surface and fur layer. As moist air is removed from the fur layer and taken up by air surrounding the cow, more moist air moves through the hair coat. The air around the cow is replaced with fresh air due to natural air movement or ventilation and thus, allows more moist air to be withdrawn from the hair coat.

Panting is a respiration process by which cow looses heat. In the cold environments, heat is lost by warming inhaled cold air before being exhaled. Whereas, in hot environments the heat is lost by vapourisation of moisture in the lungs. Cows panting at the rate of 132 breaths per minute when exposed to $36^{\circ} \mathrm{C}$ ambient air temperature, $38 \%$ relative humidity and $1.0 \mathrm{~m} / \mathrm{s}$ air velocity was observed [4]. In hot and humid conditions, air velocity of $1.0-2.2 \mathrm{~m} / \mathrm{s}$ gives desirable rates of heat and moisture movement through and from the hair coats of cows [11]. Respiration rates of $80-90$ breaths per minute indicate that cows are experiencing heat stress [5]. Berman et al. [14] found that respiratory frequency started rising above $50-60$ breaths per minute at ambient temperatures higher than $25^{\circ} \mathrm{C}$. Cows may also loose substantial proportion of body heat through respiration and therefore, it should be considered in simulation model dealing with prediction of heat loss. However, to the best of authors' knowledge, no study has yet been reported which simulates heat loss through respiration.

Cows can aiso loose heat by loosing water from their bodies. Water intake usually refers to free-drinking water plus that available in the feed. Water's physical properties make it an important factor in the transfer of heat and the regulation of temperature in the body. Since water has a high specific heat (the ability to absorb or give off heat with a relatively small change in temperature), it is ideally suited as a temperature buffering system for the body. The water consumption of dairy animals is influenced by many factors including breed, body size, ambient environment, water temperature, humidity, feed supply, salt, and level of production. One of the ways to loose water is through urine. It has been reported that dairy cattle consumes 38 - 110 liters of water per day of which almost $30 \%$ is discharged in the form urine [15]. Cows also loose body heat through urine and therefore, needs to be investigated to find out the extent to which heat is lost. To the best of authors' knowledge, no attempt has been made so far to quantify the heat loss due to loss of water in the form of urine.

The specific objective of this research is to develop a mathematical model that predicts evaporative, respiratory, convective and radiant heat losses as well as heat loss through urine from cows under stressful hot environments and to present the sensible, latent, and 
total heat losses for different ambient temperatures, relative humidity, air velocities, level of wetness, breathing rate, and volume of urine discharged. The simulated results are, however, not experimentally validated.

\section{MATHEMATICAL MODEL DEVELOPMENT}

The flow field between the animal and the environment is divided into laminar boundary layer and the turbulent boundary (convective) layer as shown in Figure 1. The laminar boundary layer consists of the sum of the thickness of fur layer $\left(\delta_{1}\right)$ and a thin film of air layer $\left(\delta_{2}\right)$ above it. Following assumptions are used in the development of the model:

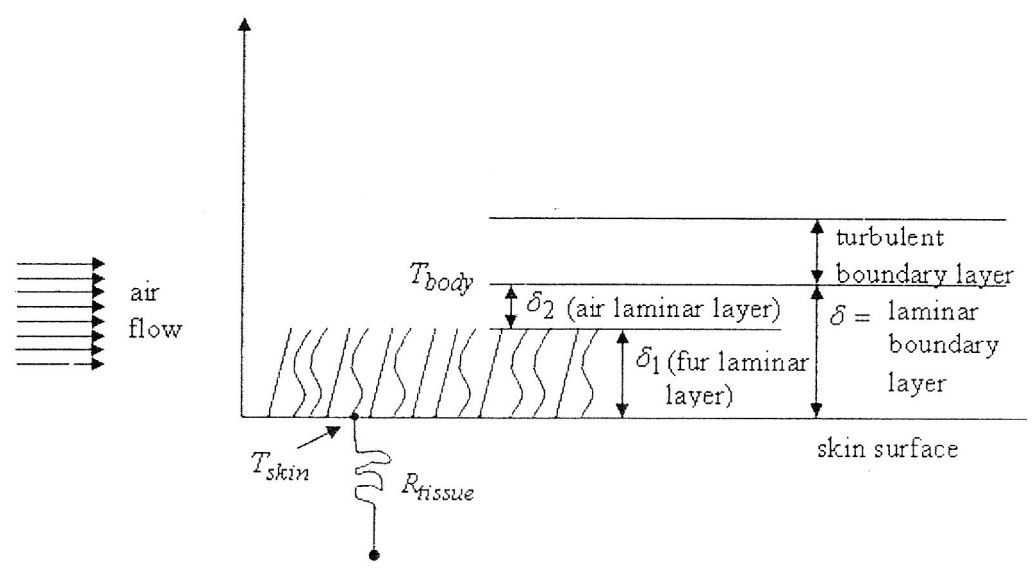

Fig. 1: Schematic diagram showing laminar and turbulent boundary layers within the fur layer [12]

Assumptions

(1) Animal geometry can be represented by a cylinder.

(2) Flow of heat and mass is assumed to be in steady state.

(3) Thermal properties of fur layer and air are assumed to be constant.

(4) Air flow within the hair coat is assumed to be laminar.

(5) The internal body temperature is assumed to be constant.

(6) Laminar boundary layer includes the fur layer and a thin film of air layer outside the hair coat. Heat conduction and molecular diffusion are considered in this layer.

(7) The skin surface is considered to be a black body.

(8) Indoor wall temperatures are assumed to be equal to ambient air temperature. 


\subsection{Theoretical model}

The evaporative heat loss $\left(Q_{\text {evap }}\right)$ in $\mathrm{kJ} /$ time is calculated as [12]:

$$
Q_{\text {evap }}=\lambda j \beta A_{S}
$$

where $\lambda$ is the latent heat of vapourisation of water at the skin-surface temperature $(\mathrm{kJ} / \mathrm{kg}$ water $), j$ is the total mass flux of water vapour $\left(\mathrm{k} \mathrm{mol} / \mathrm{m}^{2} \mathrm{~s}\right), \beta$ is the percent wet area of the skin surface ( $\%)$, and $A_{S}$ is the surface area of the animal $\left(\mathrm{m}^{2}\right)$ which can be calculated from Brody's formula [16] as $0.15 W^{0.56}$ where, $W$ is the body weight in $\mathrm{kg}$.

The total mass flux of water vapour $(j)$ that evaporates from the skin surface is calculated as [12]:

$$
j=\left(C_{\text {skin }}-C_{o}\right) /\left(\frac{1}{h_{m}}+\frac{\delta_{1}+\delta_{2}}{D}\right)
$$

where, $C_{\text {skin }}$ is the concentration of water vapour on the skin surface $\left(\mathrm{kmol} / \mathrm{m}^{3}\right), C_{O}$ is the concentration of water vapour in the ambient air $\left(\mathrm{kmol} / \mathrm{m}^{3}\right), h_{m}$ is the convective mass transfer coefficient $(\mathrm{m} / \mathrm{s}), \delta_{1}$ is the thickness of hair coat $(\mathrm{m}), \delta_{2}$ is the thickness of air laver beyond the thickness of the hair coat $(\mathrm{m})$, and $D$ is the mass diffusive coefficient of water vapour $\left(\mathrm{m}^{2} / \mathrm{s}\right)$.

The convective heat loss from the skin $\operatorname{surface}\left(Q_{\text {conv }}\right)$ in $\mathrm{kJ} /$ time is calculated as [12]:

$$
Q_{c o n v}=\left(T_{s k i n}-T_{a m b}\right) A_{s} /\left(\frac{1}{h_{c}}+\frac{\delta_{1}}{k_{e f f}}+\frac{\delta_{2}}{k_{\text {air }}}\right)
$$

where, $T_{\text {skin }}$ is the skin surface temperature $\left(\mathrm{K}\right.$ or $\left.{ }^{\circ} \mathrm{C}\right), T_{a m b}$ is the ambient air temperature $\left(\mathrm{K}\right.$ or $\left.{ }^{\circ} \mathrm{C}\right), h_{c}$ is the convective heat transfer coefficient $\left(\mathrm{W} / \mathrm{m}^{2} \mathrm{~K}\right), k_{\text {eff }}$ is the mean effective thermal conductivity of the fur layer $(\mathrm{W} / \mathrm{m} \mathrm{K})$, and $k_{\text {air }}$ is the thermal conductivity of the ambient air (W/m K).

The radiant heat loss $\left(Q_{\text {rad }}\right)$ in $\mathrm{kJ} /$ time is calculated as [13]:

$$
Q_{\text {rad }}=\varepsilon f_{\text {fur }} f_{\text {eff }} h_{r} A_{s}\left(T_{\text {skin }}-T_{\text {mrt }}\right)
$$

where, $\varepsilon$ is the radiant emissive coefficient of animal skin (non-dimensional), $f_{f u r}$ is the ratio of fur surface area to skin surface area $(\%), f_{\text {eff }}$ is the coefficient of effective radiant area (non-dimensional), $h_{r}$ is the coefficient of radiant heat transfer $\left(\mathrm{W} / \mathrm{m}^{2} \mathrm{~K}\right)$, and $T_{m r t}$ is the mean radiant temperature, assumed to be equal to the ambient temperature $\left(\mathrm{K}\right.$ or ${ }^{\circ} \mathrm{C}$ ). 
The respiratory heat loss $\left(Q_{\text {resp }}\right)$ in $\mathrm{kJ} /$ time is calculated as:

$$
Q_{\text {resp }}=\frac{B_{r}}{60}\left[R_{\text {sv }} \rho_{\text {air }} C_{\text {pair }}\left(T_{\text {body }}-T_{\text {amb }}\right)+R_{\text {sv }} \rho_{\text {air }}\left(H_{\text {exhale }}-H_{\text {inhale }}\right) h_{f g}\right]
$$

where, $B_{r}$ is the breathing rate (breaths/min). For a normal cow the average breathing rate is 38 breaths/min [17] $R_{S V}$ is the volume of air inhaled per breath. It is assumed to be $100 \mathrm{cc} / \mathrm{breath} . \rho_{\text {air }}$ is the density of air at $T_{b o d y}\left(\mathrm{~kg} / \mathrm{m}^{3}\right) C_{\text {pair }}$ is the specific heat of air at $T_{\text {body }}(\mathrm{kJ} / \mathrm{kg} \mathrm{K}) T_{\text {body }}$ is the internal body temperature $\left({ }^{\circ} \mathrm{C}\right.$ or $\left.\mathrm{K}\right) T_{a m b}$ is the ambient air temperature $\left({ }^{\circ} \mathrm{C}\right.$ or $\left.\mathrm{K}\right), H_{\text {exhale }}$ is the relative humidity of exhaled air (\%). It is assumed to be $(80 \%), H_{\text {inhale }}$ is the relative humidity of inhaled air $(\%)$, and $h_{f g}$ is the enthalpy of moist air at $T_{\text {body }}(\mathrm{kJ} / \mathrm{kg} \mathrm{K}) /$ The heat loss due to loss of water in the form of urine $\left(Q_{\text {urine }}\right)$ in $\mathrm{kJ} /$ time is calculated as:

$$
Q_{\text {urine }}=V_{\text {urine }} \rho_{\text {urine }} C_{\text {purine }}\left(T_{\text {body }}-T_{\text {amb }}\right) / 3600
$$

where, $V_{\text {urine }}$ is the volume of urine discharged $(1 / \mathrm{h}) \rho_{\text {urine }}$ is the density of urine at $T_{\text {bod }}$ $\left(\mathrm{kg} / \mathrm{m}^{3}\right)$. It is assumed to be $1020 \mathrm{~kg} / \mathrm{m}^{3}, C_{\text {purine }}$ is the specific heat of urine at $T_{\text {body }}$ $(\mathrm{kJ} / \mathrm{kg} \mathrm{K})$. It is assumed to be $4.2 \mathrm{~kJ} / \mathrm{kg} \mathrm{K}$.

The total heat loss $\left(Q_{\text {total }}\right)$ from the animal to the ambient air in $\mathrm{kJ} /$ time is calculated as:

$$
Q_{\text {total }}=Q_{\text {evap }}+Q_{\text {conv }}+Q_{\text {rad }}+Q_{\text {resp }}+Q_{\text {urine }}
$$

The skin temperature is influenced by both heat and mass transfer, and thus is coupled. The skin temperature is calculated from:

$$
Q_{\text {total }}=A_{S}\left(T_{\text {body }}-T_{\text {skin }}\right) / R_{\text {tissue }}
$$

$R_{\text {tissue }}$ is the heat resistance of tissue $\left(\mathrm{m}^{2} \mathrm{~K} / \mathrm{W}\right)$.

Combining equations (1) and (3) to (8), $T_{\text {skin }}, Q_{\text {evap }}, Q_{\text {conv }}, Q_{\text {rad }}, Q_{\text {resp }}$ and $Q_{\text {urine }}$ are solved by iteration. The details of evaluating $C_{s k i n}, C_{o}, h_{m}, \delta_{2}, D, h_{c}$, and $k_{\text {eff }}$ may be obtained from [12].

\section{RESULTS AND DISCUSSION}

The mathematical model described above is used to obtain values of skin temperature $\left(T_{\text {skin }}\right), \quad$ evaporative $\left(Q_{\text {evap }}\right), \quad$ respiratory $\left(Q_{\text {resp }}\right), \quad$ latent $\left(Q_{\text {latent }}\right)$, 
convective $\left(Q_{\text {conv }}\right), \quad \operatorname{radiant}\left(Q_{\text {rad }}\right), \quad$ urine $\left(Q_{\text {urine }}\right), \quad$ sensible $\left(Q_{\text {sensible }}\right)$, and total $\left(Q_{\text {total }}\right)$ heat losses from cows under different environmental, skin wetness, breathing, and volume of urine discharged conditions. An iterative computer program was developed to solve the mathematical equations stated in section 2.2 in order to get the desired results. The data required to run the computer program to get the results were taken from the available literature (see [12-13]). The latent heat loss, indeed, is the sum of evaporative and respiratory heat losses, the sensible heat loss is the sum of convective, radiant, and urine heat losses, and the total heat loss is the sum of latent and sensible heat losses. Following factors were kept constant in all the relationships given in this paper: internal body temperature is $38.7^{\circ} \mathrm{C}$, fur depth is $3 \mathrm{~mm}$, and hair density is 26 hairs $/ \mathrm{mm}^{2}$. Figure 2 shows the effect of wetness on latent, sensible, and total heat losses. Wetness is the ratio of wet skin to total skin surface of cow. The results shown in Figure 2 are obtained at air vclocity $1.0 \mathrm{~m} / \mathrm{s}$, ambient air temperature $30^{\circ} \mathrm{C}$, relative humidity $20 \%$, breathing rate 38 breaths $/ \mathrm{min}$, and volume of urine discharged $1.0 \mathrm{l} / \mathrm{h}$. For these conditions, it can be seen from Fig. 2 that when the level of wetness increased from 25 to $50 \%$, the evaporative heat loss is increased by $80 \%$ (Table 1). When level of wetness increased further, evaporative heat loss yet increased but at a lower rate. However, there is no effect on respiratory heat loss since it does not depend upon wetness level but it contributes significantly to the latent heat loss and thereby to the total heat loss. Increased air velocity and level of wetness assist in cooling off the skin surface of cow.

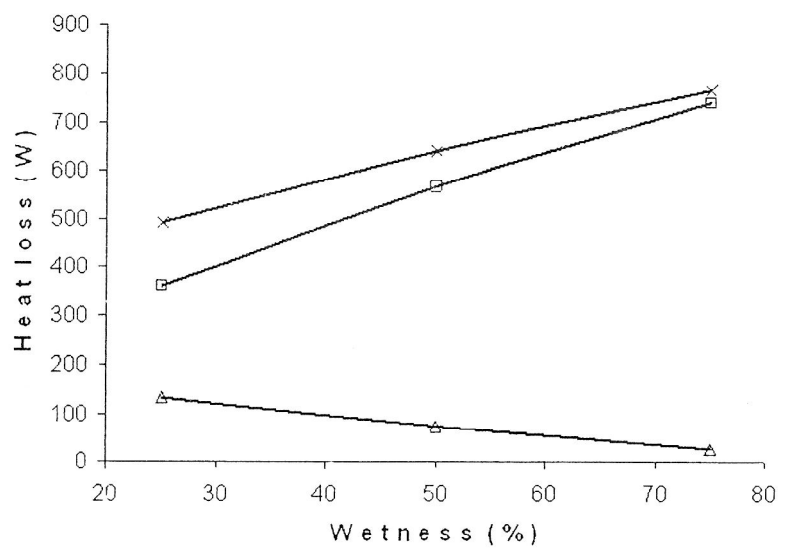

Fig. 2: Simulated latent $\left(Q_{1}\right)$, sensible $\left(Q_{s}\right)$ and total $\left(Q_{t}\right)$ heat losses as a function of percent of wetness (fixed parameters are: $1.0 \mathrm{~m} / \mathrm{s}$ air velocity, $30^{\circ} \mathrm{C}$ ambient temperature, $20 \%$ relative humidity, 38 breaths/min breathing rate, $1.0 \mathrm{l} / \mathrm{h}$ urine discharge rate, 26 hairs $/ \mathrm{mm}^{2}$ hair density, $3 \mathrm{~mm}$ fur depth and $38.7^{\circ} \mathrm{C}$ internal body temperature). 
Table 1: Skin temperature, evaporative, respiratory, latent, convective, radiative, sensible, and total heat losses as a function of air velocity and level of wetness ${ }^{\mathrm{a}}$

\begin{tabular}{lllllllllll}
\hline $\begin{array}{l}\text { Wetness } \\
\text { percent } \\
\beta(\%)\end{array}$ & $\begin{array}{l}\text { Airve } \\
\text { locity } \\
(\mathrm{m} / \mathrm{s})\end{array}$ & $\begin{array}{l}T_{\text {skin }} \\
\left({ }^{\circ} \mathrm{C}\right)\end{array}$ & $\begin{array}{l}Q_{\text {evap }} \\
(\mathrm{W})\end{array}$ & $\begin{array}{l}Q_{\text {resp }} \\
(\mathrm{W}) .\end{array}$ & $\begin{array}{l}Q_{\text {latent }} \\
(\mathrm{W})\end{array}$ & $\begin{array}{l}Q_{\text {conv }} \\
(\mathrm{W})\end{array}$ & $\begin{array}{l}Q_{\text {rad }} \\
(\mathrm{W})\end{array}$ & $\begin{array}{l}Q_{\text {urine }} \\
(\mathrm{W})\end{array}$ & $\begin{array}{l}Q_{\text {sens }} \\
(\mathrm{W})\end{array}$ & $\begin{array}{c}Q_{\text {total }} \\
(\mathrm{W})\end{array}$ \\
\hline 25 & 0.5 & 34.14 & 178.77 & 104.11 & 282.88 & 42.94 & 83.86 & 10.35 & 137.15 & 420.03 \\
& 1.0 & 33.35 & 257.50 & 104.11 & 361.62 & 53.74 & 67.76 & 10.35 & 131.85 & 493.47 \\
50 & 2.0 & 32.34 & 365.53 & 104.11 & 469.65 & 58.91 & 47.37 & 10.35 & 116.64 & 586.29 \\
& 0.5 & 32.91 & 330.28 & 104.11 & 434.39 & 30.16 & 58.89 & 10.35 & 99.40 & 533.79 \\
& 1.0 & 31.74 & 463.66 & 104.11 & 567.77 & 28.00 & 35.29 & 10.35 & 73.64 & 641.41 \\
75 & 2.0 & 30.35 & 639.73 & 104.11 & 743.84 & 8.75 & 7.04 & 10.35 & 26.14 & 769.98 \\
& 0.5 & 31.84 & 461.78 & 104.11 & 565.89 & 19.07 & 37.22 & 10.35 & 66.64 & 632.53 \\
& 1.0 & 30.40 & 635.58 & 104.11 & 739.69 & 6.51 & 8.20 & 10.35 & 25.06 & 764.75 \\
\hline
\end{tabular}

${ }^{a}$ The above predictions are based on: $30^{\circ} \mathrm{C}$ ambient temperature, $20 \%$ relative humidity, 38 breaths/minute, breathing rate, $1.0 \mathrm{l} / \mathrm{h}$ volume of urine discharged, 26 hairs $/ \mathrm{mm}^{2}$ hair density, 3 $\mathrm{mm}$ fur depth, and $38.7^{\circ} \mathrm{C}$ internal body temperature.

Figure 3 shows the effect of air velocity on latent, sensible and total heat losses for the following fixed parameters: ambient air temperature is $30^{\circ} \mathrm{C}$, relative humidity is $20 \%$, wetness level is $25 \%$, breathing rate is $38 \mathrm{breaths} / \mathrm{min}$, and volume of urine discharged is $1.0 \mathrm{l} / \mathrm{h}$. It is evident from this figure that by increasing air velocity, the convective heat loss increased (Table 1). The combined effect of wetness and air velocity on latent, sensible and total heat losses is presented in Table 1. It can be seen from this table that there is no effect of wetness and air velocity on heat loss through urine. However, its contribution is approximately $1-3 \%$ to the total heat loss.

Figure 4 shows the effect of relative humidity on latent, sensible and total heat losses when the following conditions are kept constant: air velocity is $2.0 \mathrm{~m} / \mathrm{s}$, ambient air temperature is $30^{\circ} \mathrm{C}$, breathing rate is 38 breaths $/ \mathrm{min}$, and volume of urine discharged is $1.0 \mathrm{l} / \mathrm{h}$. It can be seen from the figure that for these conditions the evaporative, respiratory and latent heat loss decrease as relative humidity increases. This happens because increase in relative humidity makes the air more saturated with water and thus, reduces its ability to absorb further water particles. The combined effect of wetness and relative humidity on latent, sensible and total heat losses is presented in Table 2. It can be seen from this table that there is no effect of wetness and relative humidity on heat loss through urine.

Figure 5 shows the effect of ambient air temperature on latent, sensible and total heat losses. These results corresponds to $2.0 \mathrm{~m} / \mathrm{s}$ air velocity, $20 \%$ relative humidity, $25 \%$ wetness, 38 breaths $/ \mathrm{min}$ breathing rate and $1.0 \mathrm{l} / \mathrm{h}$ volume of urine discharged. It can be observed from this figure that as the ambient air temperature approached the value of the skin surface temperature, sensible heat loss decreased because of lower temperature gradient. Evaporative heat loss is not significantly affected by ambient air temperature. Respiratory heat loss too is not affected since breathing rate is kept constant. However, it contributes significantly to the total heat loss. Heat is gained by the cow body when ambient temperature is more than skin temperature and heat is loosed from body when ambient temperature is lesser than skin temperature. 


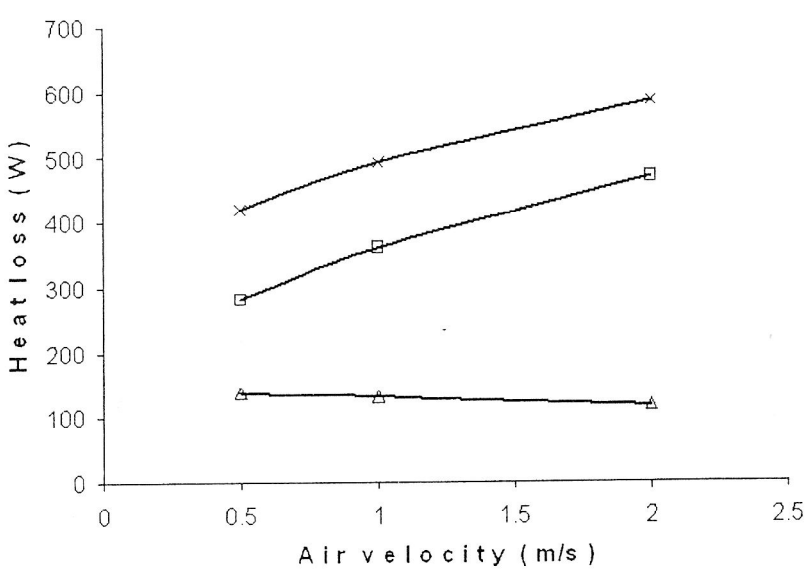

Fig. 3: Simulated latent $\left(\mathrm{Q}_{1}\right)$, sensible $\left(\mathrm{Q}_{\mathrm{s}}\right)$ and total $\left(\mathrm{Q}_{\mathrm{t}}\right)$ heat losses as a function of air velocity (fixed parameters are: $30^{\circ} \mathrm{C}$ ambient temperature, $20 \%$ relative humidity, $25 \%$ wetness, 38 breaths $/ \mathrm{min}$ breathing rate, $1.0 \mathrm{l} / \mathrm{h}$ urine discharge rate, 26 hairs $/ \mathrm{mm}^{2}$ hair density, $3 \mathrm{~mm}$ fur depth and $38.7^{\circ} \mathrm{C}$ internal body temperature).

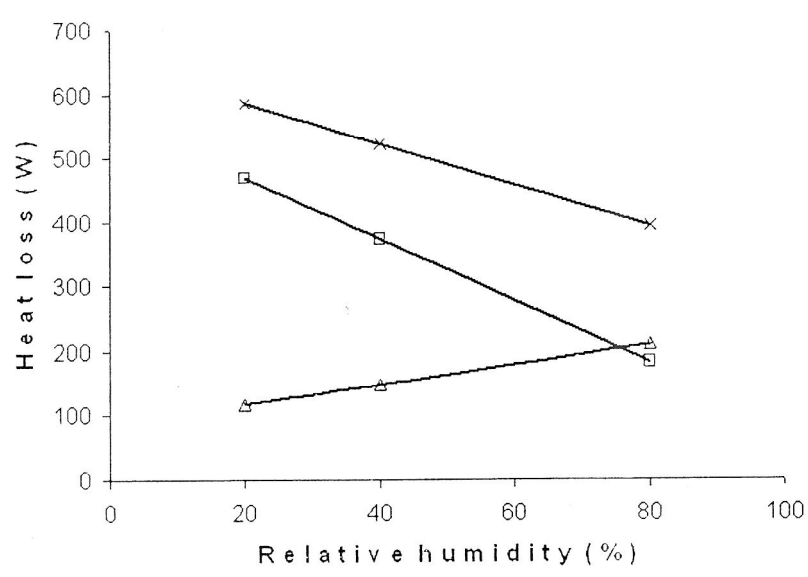

Fig. 4: Simulated latent $\left(Q_{1}\right)$, sensible $\left(Q_{s}\right)$ and total $\left(Q_{t}\right)$ heat losses as a function of relative humidity (fixed parameters are: $2.0 \mathrm{~m} / \mathrm{s}$ air velocity, $30^{\circ} \mathrm{C}$ ambient temperature, $25 \%$ wetness, 38 breaths $/ \mathrm{min}$ breathing rate, $1.0 \mathrm{l} / \mathrm{h}$ urine discharge rate, 26 hairs $/ \mathrm{mm}^{2}$ hair density, $3 \mathrm{~mm}$ fur depth and $38.7^{\circ} \mathrm{C}$ internal body temperature).

The combined effect of wetness and ambient air temperature on latent, sensible and total heat losses is shown in Table 3. It can be seen from this table that latent heat loss increases with increasing level of wetness and ambient temperature, whereas, sensible heat 
loss decreases with increasing level of wetness and ambient temperature. It can also be seen that for a given wetness level, heat loss through urine decreases with increasing ambient temperature.Fig. 4: Simulated latent $\left(Q_{l}\right)$, sensible $\left(Q_{s}\right)$ and total $\left(Q_{t}\right)$ heat losses as a function of relative humidity (fixed parameters are: $2.0 \mathrm{~m} / \mathrm{s}$ air velocity, $30^{\circ} \mathrm{C}$ ambient temperature, $25 \%$ wetness, 38 breaths $/ \mathrm{min}$ breathing rate, $1.0 \mathrm{l} / \mathrm{h}$ urine discharge rate, 26 hairs $/ \mathrm{mm}^{2}$ hair density, $3 \mathrm{~mm}$ fur depth and $38.7^{\circ} \mathrm{C}$ internal body temperature).

Table 2: Skin temperature, evaporative, respiratory, latent, convective, radiative, sensible, and total heat losses as a function of relative humidity and level of wetness ${ }^{\text {a }}$

\begin{tabular}{ccccccccccc}
$\begin{array}{l}\text { Wetness } \\
\text { percent }\end{array}$ & $\begin{array}{c}\text { Relative } \\
\text { humidity } \\
\beta(\%)\end{array}$ & $\begin{array}{c}T_{\text {skin }} \\
\left({ }^{\circ} \mathrm{C}\right)\end{array}$ & $\begin{array}{c}Q_{\text {evap }} \\
(\mathrm{W})\end{array}$ & $\begin{array}{c}Q_{\text {resp }} \\
(\mathrm{W})\end{array}$ & $\begin{array}{c}Q_{\text {latent }} \\
(\mathrm{W})\end{array}$ & $\begin{array}{c}Q_{\text {conv }} \\
(\mathrm{W})\end{array}$ & $\begin{array}{c}Q_{\text {rad }} \\
(\mathrm{W})\end{array}$ & $\begin{array}{c}Q_{\text {urine }} \\
(\mathrm{W})\end{array}$ & $\begin{array}{c}Q_{\text {sens }} \\
(\mathrm{W})\end{array}$ & $\begin{array}{c}Q_{\text {total }} \\
(\mathrm{W})\end{array}$ \\
\hline 25 & 20 & 32.34 & 365.53 & 104.11 & 469.65 & 58.91 & 47.37 & 10.35 & 116.64 & 586.29 \\
& 40 & 33.04 & 304.12 & 69.62 & 373.74 & 76.44 & 61.48 & 10.35 & 148.27 & 522.02 \\
50 & 80 & 34.72 & 182.34 & 0.63 & 182.97 & 111.31 & 89.55 & 10.35 & 211.21 & 394.18 \\
& 20 & 30.35 & 639.73 & 104.11 & 743.84 & 8.75 & 7.04 & 10.35 & 26.14 & 769.98 \\
& 40 & 31.39 & 530.16 & 69.62 & 599.78 & 35.12 & 28.23 & 10.35 & 73.70 & 673.49 \\
75 & 80 & 33.46 & 315.29 & 0.63 & 315.92 & 87.00 & 69.98 & 10.35 & 163.74 & 483.26 \\
& 20 & 28.75 & 859.07 & 104.11 & 963.19 & -31.37 & -25.21 & 10.35 & -46.23 & 916.95 \\
& 40 & 30.10 & 708.91 & 69.62 & 778.53 & 2.41 & 1.94 & 10.35 & 14.71 & 793.23 \\
& 80 & 32.71 & 418.03 & 0.63 & 418.65 & 68.23 & 54.88 & 10.35 & 133.46 & 552.12 \\
\hline
\end{tabular}

${ }^{a}$ The above predictions are based on: $30^{\circ} \mathrm{C}$ ambient temperature, $2 \mathrm{~m} / \mathrm{s}$ air velocity, 38 breaths $/$ minute, breathing rate, $1.0 \mathrm{l} / \mathrm{h}$ volume of urine, 26 hairs $/ \mathrm{mm}^{2}$ hair density, $3 \mathrm{~mm}$ fur depth, and $38.7^{\circ} \mathrm{C}$ internal body temperature.

Table 3: Skin temperature, evaporative, respiratory, latent, convective, radiative, sensible, and total heat losses as a function of ambient temperature and level of wetness ${ }^{\mathrm{a}}$

\begin{tabular}{ccccccccccc}
$\begin{array}{c}\text { Wetness } \\
\text { percent } \\
\beta(\%)\end{array}$ & $\begin{array}{c}T_{\text {amb }} \\
\left({ }^{\circ} \mathrm{C}\right)\end{array}$ & $\begin{array}{c}T_{\text {skin }} \\
\left({ }^{\circ} \mathrm{C}\right)\end{array}$ & $\begin{array}{c}Q_{\text {evap }} \\
(\mathrm{W})\end{array}$ & $\begin{array}{c}Q_{\text {resp }} \\
(\mathrm{W})\end{array}$ & $\begin{array}{c}Q_{\text {latent }} \\
(\mathrm{W})\end{array}$ & $\begin{array}{c}Q_{\text {conv }} \\
(\mathrm{W})\end{array}$ & $\begin{array}{c}Q_{\text {rad }} \\
(\mathrm{W})\end{array}$ & $\begin{array}{c}Q_{\text {urine }} \\
(\mathrm{W})\end{array}$ & $\begin{array}{c}Q_{\text {sens }} \\
(\mathrm{W})\end{array}$ & $\begin{array}{c}Q_{\text {total }} \\
(\mathrm{W})\end{array}$ \\
\hline 25 & 30 & 32.34 & 365.53 & 104.11 & 469.65 & 58.91 & 47.37 & 10.35 & 116.64 & 586.29 \\
& 35 & 33.89 & 385.10 & 103.75 & 488.85 & -27.79 & -22.38 & 4.40 & -45.76 & 443.09 \\
50 & 38 & 34.83 & 395.72 & 103.54 & 499.26 & -79.54 & -64.10 & 0.83 & -142.81 & 356.45 \\
& 30 & 30.35 & 639.73 & 104.11 & 743.84 & 8.75 & 7.04 & 10.35 & 26.14 & 769.98 \\
& 35 & 31.84 & 667.92 & 103.75 & 771.67 & -79.49 & -63.98 & 4.40 & -139.06 & 632.61 \\
75 & 38 & 32.75 & 682.49 & 103.54 & 786.02 & -131.95 & -106.25 & 0.83 & -237.41 & 548.61 \\
& 30 & 28.75 & 859.07 & 104.11 & 963.19 & -31.37 & -25.21 & 10.35 & -46.23 & 916.95 \\
& 35 & 30.22 & 890.96 & 103.75 & 994.71 & -120.30 & -96.80 & 4.40 & -212.69 & 782.02 \\
& 38 & 31.12 & 906.71 & 103.54 & 1010.25 & -172.93 & -139.2 & 0.83 & -311.35 & 698.90 \\
\hline
\end{tabular}

The above predictions are based on: $20 \%$ relative humidity, $2 \mathrm{~m} / \mathrm{s}$ air velocity, 38 breaths $/$ minute, breathing rate, $1.0 \mathrm{l} / \mathrm{h}$ volume of urine, 26 hairs $/ \mathrm{mm}^{2}$ hair density, $3 \mathrm{~mm}$ fur depth, and $38.7^{\circ} \mathrm{C}$ internal body temperature. 


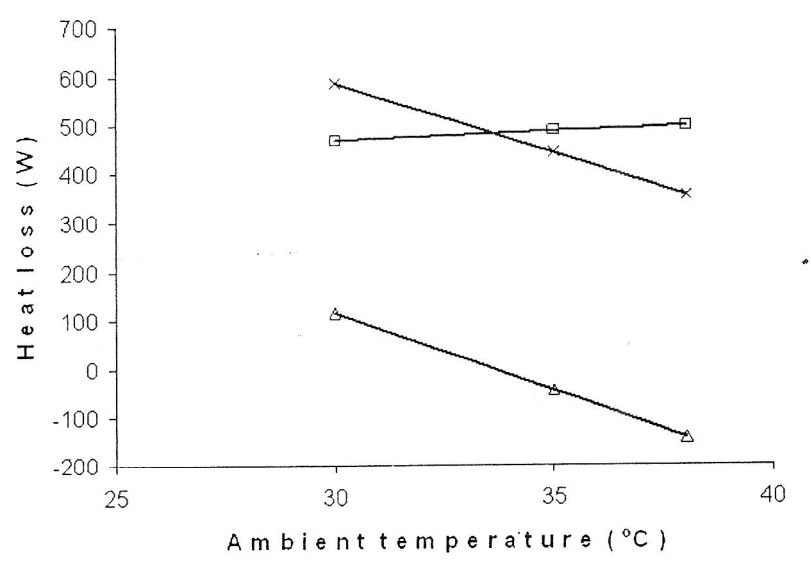

Fig. 5: Simulated latent $\left(Q_{l}\right)$, sensible $\left(Q_{s}\right)$ and total $\left(Q_{t}\right)$ heat losses as a function of ambient temperature (fixed parameters are: $2.0 \mathrm{~m} / \mathrm{s}$ air velocity, $20 \%$ relative humidity, $25 \%$ wetness, 38 breaths $/ \mathrm{min}$ breathing ratc, $1.01 / \mathrm{h}$ urine discharge rate, 26 hairs $/ \mathrm{mm}^{2}$ hair density, $3 \mathrm{~mm}$ fur depth and $38.7^{\circ} \mathrm{C}$ internal body temperature).

Figure 6 shows the effect of breathing rate on latent, sensible and total heat losses. The results shown in this figure are for $30^{\circ} \mathrm{C}$ ambient air temperature, $2.0 \mathrm{~m} / \mathrm{s}$ air velocity, $20 \%$ relative humidity, $25 \%$ wetness and $1.0 \mathrm{l} / \mathrm{h}$ volume of urine discharged. The breathing rates considered in this analysis range from 40 to 80 breaths $/ \mathrm{min}$. 40 breaths $/ \mathrm{min}$ corresponds to breathing rate of a normal cow under the normal environmental conditions where as 80 breaths/min corresponds to breathing rate of a cow under stressful hot environment. For these conditions, respiratory heat loss increased by $50 \%$ when the breathing rate increased from 40 to 60 (Table 4). When the breathing rate was further increased from 60 to 80 , respiratory heat loss yet increased but at a lower rate $(33 \%)$. The latent heat loss increases with increase in breathing rate and thus, causes cooling of the skin surface which, in turn decreases the temperature gradient between the skin surface and ambient air resulting in decreased convective and radiative heat losses. The combined effect of breathing rate and wetness level on heat loss is shown in Table 4. It can be seen from this table that there is no effect of wetness and breathing rate on heat loss through urine.

Figure 7 shows the effect of volume of urine discharged on latent, sensible and total heat losses. The results shown in this figure are for $30^{\circ} \mathrm{C}$ ambient air temperature, $2.0 \mathrm{~m} / \mathrm{s}$ air velocity, $20 \%$ relative humidity, $25 \%$ wetness and 38 breaths/min breathing rate. The volume of urine discharged considered in this analysis ranges from 0.5 to $1.5 \mathrm{l} / \mathrm{h}$. This corresponds to the case when cow consumes water that ranges from 38 to 120 liters per day. The effect of change in volume of urine discharged on latent and sensible heat losses is found to be very small even though, the heat loss through urine is increased by a small amount due to increase in the volume of urine discharged. The combined effect of volume of urine discharged and wetness level on heat loss is shown in Table 5. It can be seen from 
this table that there is an insignificant effect of wetness and volume of urine discharged on heat loss through urine.

Table 4: Skin temperature, evaporative, respiratory, latent, convective, radiative, sensible, and total heat losses as a function of br athing rate and level of wetness ${ }^{\mathrm{a}}$

\begin{tabular}{ccccccccccc}
\hline $\begin{array}{c}\text { Wetness } \\
\text { percent } \\
\beta(\%)\end{array}$ & $\begin{array}{c}\text { Breathin } \\
\text { g rate } \\
\text { breath/m } \\
\text { in) }\end{array}$ & $\begin{array}{c}T_{\text {skin }} \\
\left({ }^{\circ} \mathrm{C}\right)\end{array}$ & $\begin{array}{c}Q_{\text {cvap }} \\
(\mathrm{W})\end{array}$ & $\begin{array}{c}Q_{\text {resp }} \\
(\mathrm{W})\end{array}$ & $\begin{array}{c}Q_{\text {latent }} \\
(\mathrm{W})\end{array}$ & $\begin{array}{c}Q_{\text {conv }} \\
(\mathrm{W})\end{array}$ & $\begin{array}{c}Q_{\text {rad }} \\
(\mathrm{W})\end{array}$ & $\begin{array}{c}Q_{\text {urine }} \\
(\mathrm{W})\end{array}$ & $\begin{array}{c}Q_{\text {sens }} \\
(\mathrm{W})\end{array}$ & $\begin{array}{c}Q_{\text {total }} \\
(\mathrm{W})\end{array}$ \\
\hline \multirow{2}{*}{25} & 40 & 32.31 & 364.71 & 109.59 & 474.30 & 58.05 & 46.68 & 10.35 & 115.08 & 589.39 \\
& 60 & 31.97 & 356.64 & 164.39 & 521.03 & 49.51 & 39.81 & 10.35 & 99.68 & 620.70 \\
& 80 & 31.63 & 348.67 & 219.19 & 567.86 & 40.95 & 32.92 & 10.35 & 84.22 & 652.08 \\
50 & 40 & 30.32 & 638.41 & 109.59 & 748.00 & 7.99 & 6.42 & 10.35 & 24.77 & 772.77 \\
& 60 & 30.02 & 625.32 & 164.39 & 789.71 & 0.38 & 0.31 & 10.35 & 11.05 & 800.76 \\
& 80 & 29.71 & 612.34 & 219.19 & 831.53 & -7.27 & -5.85 & 10.35 & -2.77 & 828.76 \\
75 & 40 & 28.73 & 857.36 & 109.59 & 966.95 & -32.08 & -25.78 & 10.35 & -47.51 & 919.44 \\
& 60 & 28.45 & 840.68 & 164.39 & 1005.07 & -39.06 & -31.39 & 10.35 & -60.10 & 944.97 \\
& 80 & 28.17 & 824.16 & 219.19 & 1043.35 & -46.07 & -37.01 & 10.35 & -72.73 & 970.62 \\
\hline
\end{tabular}

${ }^{a}$ The above predictions are based on: $30^{\circ} \mathrm{C}$ ambient temperature, $20 \%$ relative humidity, $2 \mathrm{~m} / \mathrm{s}$ air velocity, $1.0 \mathrm{l} / \mathrm{h}$ volume of urine, 26 hairs $/ \mathrm{mm}^{2}$ hair density, $3 \mathrm{~mm}$ fur depth, and $38.7^{\circ} \mathrm{C}$ internal body temperature.

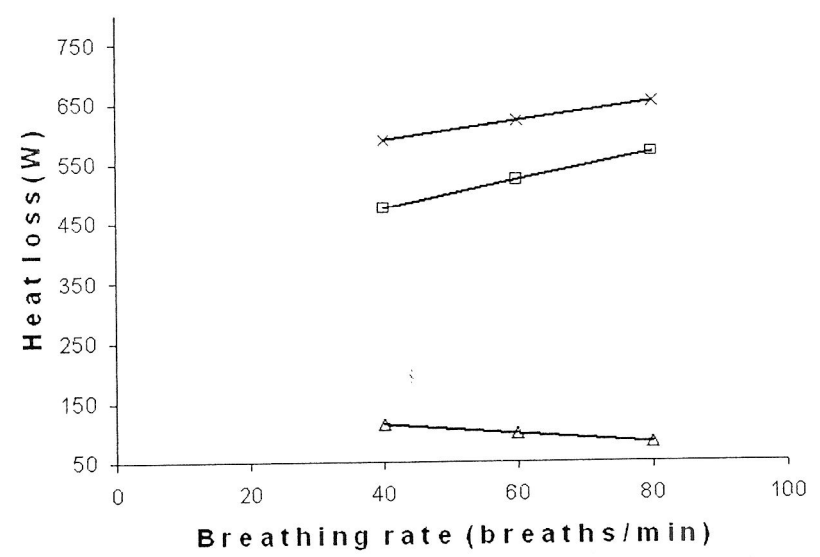

Fig. 6: Simulated latent $\left(Q_{l}\right)$, sensible $\left(Q_{s}\right)$ and total $\left(Q_{t}\right)$ heat losses as a function of breathing rate (fixed parameters are: $2.0 \mathrm{~m} / \mathrm{s}$ air velocity, $30^{\circ} \mathrm{C}$ ambient temperature, $20 \%$ relative humidity, $25 \%$ wetness, $1.0 \mathrm{l} / \mathrm{h}$ urine discharge rate, 26 hairs $/ \mathrm{mm}^{2}$ hair density, 3 $\mathrm{mm}$ fur depth and $38.7^{\circ} \mathrm{C}$ internal body temperature). 


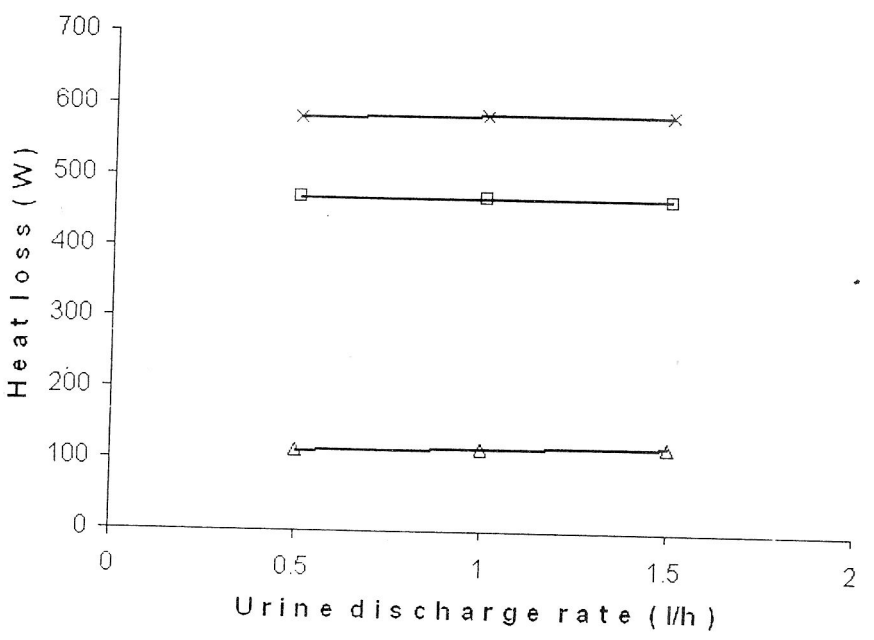

Fig. 7: Simulated latent $\left(Q_{1}\right)$, sensible $\left(Q_{S}\right)$ and total $\left(Q_{t}\right)$ heat losses as a function of urine discharge rate (fixed parameters are: $2.0 \mathrm{~m} / \mathrm{s}$ air velocity, $30^{\circ} \mathrm{C}$ ambient temperature, $20 \%$ relative humidity, $25 \%$ wetness, 38 breaths $/ \mathrm{min}$ breathing rate, 26 hairs $/ \mathrm{mm}^{2}$ hair density, $3 \mathrm{~mm}$ fur depth and $38.7^{\circ} \mathrm{C}$ internal body temperature)

Table 5: Skin temperature, evaporative, respiratory, latent, convective, radiative, sensible, and total heat losses as a function of volume of urine discharged and level of wetness $^{\mathrm{a}}$

\begin{tabular}{ccccccccccc}
\hline $\begin{array}{c}\text { Wetness } \\
\text { percent } \\
\beta(\%)\end{array}$ & $\begin{array}{c}V_{\text {urix }} \\
(1 / \mathrm{h})\end{array}$ & $\begin{array}{c}T_{\text {skin }} \\
\left({ }^{\circ} \mathrm{C}\right)\end{array}$ & $\begin{array}{c}Q_{\text {evap }} \\
(\mathrm{W})\end{array}$ & $\begin{array}{c}Q_{\text {resp }} \\
(\mathrm{W})\end{array}$ & $\begin{array}{c}Q_{\text {latent }} \\
(\mathrm{W})\end{array}$ & $\begin{array}{c}Q_{\text {conv }} \\
(\mathrm{W})\end{array}$ & $\begin{array}{c}Q_{\text {rad }} \\
(\mathrm{W})\end{array}$ & $\begin{array}{c}Q_{\text {urine }} \\
(\mathrm{W})\end{array}$ & $\begin{array}{c}Q_{\text {sens }} \\
(\mathrm{W})\end{array}$ & $\begin{array}{c}Q_{\text {total }} \\
(\mathrm{W})\end{array}$ \\
\hline 25 & 0.5 & 32.37 & 366.31 & 104.11 & 470.42 & 59.72 & 48.03 & 5.18 & 112.93 & 583.35 \\
& 1.0 & 32.34 & 365.53 & 104.11 & 469.65 & 58.91 & 47.37 & 10.35 & 116.64 & 586.29 \\
50 & 1.5 & 32.31 & 364.76 & 104.11 & 468.87 & 58.10 & 46.72 & 15.53 & 120.35 & 589.23 \\
& 0.5 & 30.38 & 641.00 & 104.11 & 745.12 & 9.49 & 7.63 & 5.18 & 22.29 & 767.41 \\
75 & 1.0 & 30.35 & 639.73 & 104.11 & 743.84 & 8.75 & 7.04 & 10.35 & 26.14 & 769.98 \\
& 1.5 & 30.32 & 638.50 & 104.11 & 742.61 & 8.04 & 6.46 & 15.53 & 30.04 & 772.65 \\
& 0.5 & 28.78 & 860.66 & 104.11 & 964.78 & -30.71 & -24.68 & 5.18 & -50.22 & 914.56 \\
& $1 . .0$ & 28.75 & 859.07 & 104.11 & 963.19 & -31.37 & -25.21 & 10.35 & -46.23 & 916.95 \\
& 1.5 & 28.73 & 857.48 & 104.11 & 961.60 & -32.03 & -25.74 & 15.53 & -42.25 & 919.35
\end{tabular}

The above predictions are based on: $30^{\circ} \mathrm{C}$ ambient temperature, $20 \%$ retave he $-\frac{-425}{919.35}$ air velocity, 38 breaths/minute breathing $38.7^{\circ} \mathrm{C}$ internal body temperature.

\section{CONCLUSIONS}

A model that predicts evaporative, respiratory, convective, radiant and urine heat losses from the skin surface and hair coat of a cow is presented. Parametric studies using the model are carried out to determine the effect of different levels of percent of wetness, air velocity, ambient air temperature, relative humidity, breathing rate, volume of urine 
discharged on different heat losses. Based on the simulated results from this study, following conclusions can be drawn:

- The increase in wetness increases evaporative cooling significantly which is further enhanced when air is simultaneously blown over the cow body. Evaporative cooling, indeed, is found to be the main cooling mechanism for heat-stressed cows.

- Evaporative and respiratory heat losses decrease with increasing relative humidity due to increased saturation of air with water particles. Evaporative heat loss did not change significantly when the ambient air temperature was varied from $30^{\circ} \mathrm{C}$ to $38^{\circ} \mathrm{C}$. However, the convective heat loss decreased with the increase in air temperature due to decreasing temperature gradient between the skin surface and ambient air.

- The contribution of respiratory heat loss to the total heat loss is found to be significant. It increased further with increasing breathing rate. Breathing at faster rate in stressful hot condition is an effective mode of cooling the body. Reasonably good proportion of total body heat is lost through respiration particularly at higher breathing rate owing to stressful hot conditions.

- The contribution of heat loss through urine to the total heat loss is very small. Change in volume of urine discharged as well as skin wetness does not produce any significant effect on heat loss through urine.

\section{REFERENCES}

[1] C.T. Kadzere, M.R. Murphy, N. Silanikove, and E. Maltz, "Heat stress in lactating dairy cows: a review," Livestock Production Science, Vol. 77, pp. 59-91, 2002.

[2] M.O. Igono, B.J. Stevens, M.D. Shanklin, and H.D. Johnson, "Spray cooling effects on milk production, milk, rectal temperatures of cows during moderate temperature summer season," Journal of Dairy Science, Vo!. 68, pp. 979-985, 1985

[3] J.C. Garner, R.A. Bucklin, W.E. Eunkle, and R.A. Nordstedt, "Sprinkled water and fans to reduce heat stress of beef cattle," Applied Engineering Agriculture, Vol. 5, pp. 99-101, 1989.

[4] P.E. Hillman and K.G. Gebremedhin, "A portable calorimeter to measure heat transfer in livestock," ASAE Paper No. 994212, ASAE, St. Joseph, Mï, 1999.

[5] R.R. Stowell, "Heat stress relief and supplemental cooling," Dairy Housing and Equipment Systems Conference Proceedings Publ. No. 129 of the Natural Resource, Agriculture, and Engineering Service (NRAES). Agricultural and Biological Engineering Department, Cornell University, Ithaca, NY, 2000

[6] J.C. Lin, B.R. Moss, J.L. Koon, C.A. Flood, R.C. Smith III, K.A. Cummins, and D.A. Coleman, "Comparison of various fan, sprinkler, and mister systems in reducing heat stress in dairy cows," Applied Engineering Agriculture, Vol. 14, pp. 177-182, 1998.

[7] I. Flamenbaum, D. Wolfenson, M. Mamen, and A. Berman, "Cooling dairy cattle by a combination of sprinkling and forced ventilation and its implementation in the shelter system," Journal of Dairy Science, Vol. 69, pp. 3140-3147, 1986. 
[8] M.O. Igono, H.D. Johnson, B.J. Stevens, G.F. Krause, and M.D. Shanklin, "Physiological, productive, and economic benefits of shade, spray, and fan system versus shade for Holstein cows during summer heat," Journal of Dairy Science, Vol. 70, pp. 1069-1079, 1987.

[9] E. Kimmel, H. Arkin, and A. Berman, "Evaporative cooling of cattle: transport phenomena and thermo vision," Presented at the 1992 ASAE Summer International Meeting, Paper No. 924028, ASAE, 2950 Niles Rd., St. Joseph, MI 49085-9659, USA, 1992.

[10] L.W. Turner, J.P. Chastain, R.W. Hemken, R.S. Gates, and W.L. Crist, "Reducing heat stress in dairy cows through sprinkler and fan cooling," Applied Engineering Agriculture, Vol. 8, pp. 251-256, 1992.

[11] J.P. Chastain and L.W. Turner, "Practical results of a model of direct evaporative cooling of dairy cows," In: Bucklin, R. (Ed.), Dairy system for the 21 st Century, Proceedings of the third International Dairy Housing Conference. ASAE, St. Joseph, MI, pp. 337-352, 1994.

[12] K.G. Gebremedhin and B. Wu, "A model of evaporative cooling of wet skin surface and fur layer," Journal of Thermal Biology, Vol. 26, pp. 537-545, 2001.

[13] K.G. Gebremedhin and B. Wu, "Simulation of sensible and latent heat losses from wet-skin surface and fur layer," Journal of Thermal Biology, Vol. 27, pp. 291-297, 2002.

[14] A. Berman, Y.M. Folman, M. Kaim, Z. Mamen, D. Herz, A. Wolfenson, and Y. Graber, “ Upper critical temperatures and forced ventilation effects for high-yielding dairy cows in a tropical climate," Journal of Dairy Science, Vol. 52, pp. 305-312, 1985.

[15] M.L. Nelson,"Water_www.ansci.wsu.edu/courses/as314/notes/AS_314_Water.ppt," 2204.

[16] S. Brody, "Bioenergetics and growth," Reinhold, New York, 1945.

[17] http://dairyalliance.psu.edu/pdf/CowSenseLaminatedHandouts.pdf_Cow Sense: Hands-On Evaluation \& Inspection. PENNSTATE, College of Agricultural Sciences 
